Ssciendo Studia Anglica Posnaniensia 54s1 (2019): 251-266

doi: 10.2478/stap-2019-0012

\title{
THE HYPOTHESIS OF CHANGE FROM ABOVE IN THE HISTORY OF ENGLISH: STATE OF THE ART AND PERSPECTIVES
}

\author{
NIKOLAOS LAVIDAS ${ }^{1}$
}

\begin{abstract}
The present paper presents the state of the art of research related to hypothesized changes from above in the diachrony of English. A main aim of the paper is to show how the cooperation of various perspectives can open new directions in the research of language change. We examine the main aspects of a definition of the change from above. We investigate the various perspectives through which the concept of change from above, as an "importation of elements from other systems" (Labov 2007), has been considered a significant factor for the development of English. We show that any attempt to investigate the presence or role of change from above includes the parameters of prestige, distribution of old and new forms, diffusion, gender, and linguistic ideology. Finally, we discuss typical examples of development of patterns and characteristics of English that have been analyzed as influenced by change from above, as well as the prestige dialects / languages and contexts that have been regarded as facilitating a hypothesized change from above (Latin, Anglo-Norman, standardization, prescriptivism, networks and individuals). We argue that the articles of the present special issue provide stable criteria that are required in any attempt to test the hypothesis of change from above in the development of English.
\end{abstract}

Keywords: Change from above; English historical linguistics; language contact.

\section{Introduction}

Change from above refers to the consciousness dimension of language change, to changes that come from above the level of a speaker's conscious awareness (cf. Labov 1965, 1994). It concerns cases of borrowing from languages that the dominant classes consider prestigious, or conscious selection, such as the retention and the re-introduction of the affirmative $d o$ in $17^{\text {th }}$-century documents (cf., e.g., Rissanen 1991) or the diachrony of negative concord (among others,

$1 \quad$ National and Kapodistrian University of Athens; nlavidas@enl.uoa.gr. 
Nevalainen 2006). Although a vivid debate still exists on the role of change from above in the history of English, a systematic discussion of the possibility of change from above appears only sporadically in various studies, and an analysis of its various aspects at different stages of the development of English is out of the scope of most previous studies. In this respect, a holistic investigation of the role of change from above (which may vary in previous studies from a peripheral to a central role in transitional stages) is a desideratum that the present article and special issue wants to fulfil.

\section{Change from above: Searching for a definition}

One of the most frequent sources of debate even concerns the definition of change from above. For Labov (2007: 346), change from above is connected to the assumption that faithful linguistic "transmission of the adult system, including variable elements" is an "unbroken sequence of native-language acquisition by children". Accordingly, two major types of change can be distinguished: (i) internal language change or change from within the system, or, change from below (cf. also Macaulay 2006: 280), and (ii) change from above or the importation of elements from other systems (Labov 2007: 346). ${ }^{2,3}$ Change from above does not refer to parameters involved in the notions of "higher" or "lower" on the socioeconomic scale (Labov 2007: 346, fn. 2). Moreover, change from above may describe the case of diffusion of nonstandard elements from other systems (such as in the recent spread of features of the dialect of London to dialects of other British cities; Trudgill 1974). For other scholars, the contrast between change from below and change from above often (or, even always) pertains both to cases of change initiated by speakers socially lower down / higher up the scale and cases of change triggered by systematic factors below / above the level of conscious awareness (Denison 2007). For Denison (2007), it is not easy to keep the two types of change apart in historical sociolinguistic investigations: studies on historical change often just describe change in some characteristics or patterns between period A and period B and do not distinguish

2 For Labov, change from above is mainly identified with "learning, primarily by adults, who acquire the new variants of the originating community" (2007: 380)

3 See also the definition in Labov (1994: 78): "Any general consideration of linguistic change must first distinguish between change from above and change from below [...] "Above" and "below" refer here simultaneously to levels of social awareness and positions in the socioeconomic hierarchy [but, for Labov (2007), change from above is not related to the socioeconomic hierarchy]. Changes from above are introduced by the dominant social class, often with full public awareness [...] Changes from below are systematic changes that appear first in the vernacular, and represent the operation of internal, linguistic factors. At the outset, and through most of their development, they are completely below the level of social awareness $[\ldots] "$. 
between change from above and change from below in their explanations. The latter observation is related to the lack of consensus on the existence of change from above. Bickerton (1980), for instance, states that all linguistic processes occur below the level of consciousness and that speakers assign them "conscious social evaluations" only post-hoc.

\section{Change from above: The important questions}

One of the main aims of this article is to examine the different perspectives through which the concept of change from above, as an "importation of elements from other systems" (Labov 2007), has been considered a parameter for the diachronic development of English. We will discuss several case studies and we will demonstrate how the types of explanations related to change from above are strictly influenced by the theory of language.

A major question that arises in any exploration of the factors that may trigger language change is the status and role of change from above. The answers vary from offering change from above as a nonexistent, nonlinguistic, or too peripheral role, to considering it a possible situation in transitional / internalized diglossia stages, ${ }^{4}$ or even to treating it as evidence for deliberate language changes (associated with gender or social classes). The common characteristic of all approaches is that they analyze change from above as related to language contact. The assumed relationship between change from above and language contact is unavoidable if change from above is identified with borrowing from a prestigious language.

Change from above is also involved in any case where characteristics of an earlier language system, for instance, still survive antagonistically to new characteristics. The case of contact between dialects of the same language should also be addressed, when one of them has become the prestigious dialect. See, for instance, the changes in rhoticity in New York, according to Labov (1966 [2006]) (cf. also Labov, Ash \& Boberg 2006). These types of contact can lead to diglossia and parallel grammars ("bilingual" speakers may use one or the other system according to the register), or prescriptive rules. ${ }^{5}$

Labov's paradigm case concerns the reintroduction of post-vocalic / $/ \mathrm{r} / \mathrm{in} \mathrm{New}$ York City English as a prestige feature. The source of the reintroduced feature is the /r/-ful pronunciation of American English. This development exemplifies a case of dialect contact / importation of a prestige norm from an external dialect (Labov 1966 [2006]: 499; Guy 1990). We should notice that there is, however,

On internalized diglossia stages, see Kroch (1989).

See, for instance, van Gelderen's (2004) study on split infinitives and relative pronouns; or, Curzan's (2014) study on the effects of prescriptivism on the history of English. 
no evidence of imposition: for instance, we do not observe the case of large numbers of non-New Yorkers learning the New York City dialect and imposing their /r/-ful pronunciation (Guy 1990).

A second major question that arises refers to the hypothesis that changes from above can only delay the introduction of new characteristics or the completion of atypical changes. ${ }^{6}$ Studies that have supported the view that change from above can initiate the introduction of new features are not missing from the relevant literature. In this respect, the first stages of the development of the English passive progressive have been analyzed as "a conscious use of a restricted group of people" (Denison 1993, among others).

Any discussion of change from above is directly related to the role and value of all types of texts and registers for the particular paths of change and spread of a change. It seems that the historical research, when "cleaned" from learned registers in order to approach the vernacular of a particular period, leaves several unexplained aspects of the diachronic development, such as cases of delay in the spread of a change / completion of a change, or reintroduction of earlier features.

\section{Aspects of changes from above}

Any attempt to investigate the presence or role of change from above includes discussion of the following parameters: prestige, distribution of old and new forms, diffusion, gender, and linguistic ideology.

Examples of change from above can be recognized in cases of borrowing from other speech communities that are considered as having higher prestige in terms of the dominant class (Labov 1994: 78). This type of borrowing does not appear in the patterns of the vernacular of any class but mainly affects careful speech and represents a superposed dialect that speakers learn after acquiring the vernacular. Moreover, change from above seems to be involved in the "redistribution of forms with known prestige values within the community" (Labov 2001: 274). A prestige feature can be identified as belonging to the language of the highest-status group and may not be found in the everyday language of the majority of speakers (Labov 1966 [2006]: 325-326). Such situations also reflect dialect contact (Guy 1990).

Several studies have shown that prestige often motivates borrowing and that the adopters of the new norms (who belong to the dominant social class) have the need to access prestigious norms (Kim 2012). Borrowing is also related to shifts from one language to another, which have been analyzed by Labov (2001: 274) as conscious shifts and changes from above. Furthermore, we should notice that formal styles demonstrate a significant rate of occurrence of changes from above

6 See, for instance, the early approach of Kroch (1978). 
(Labov 2001: 274): Nevalainen \& Raumolin-Brunberg (2003) have argued that changes from above spread from official letters, legal English, and expository treatises to other genres.

Diffusion describes change in the case of borrowing of dialect features, which spread from one community to another as a result of contact between adults. According to several studies, diffusion may result in simplification and irregularity. Many scholars have recognized diffusion as a significant part of the process involved in changes from above because speakers tend to be more aware of diffusion than other changes (Kerswill 1996; Labov 2007).

Ideological evaluation of variation motivates instances of change of the type of change from above. We can trace the role of ideological evaluation of variation, for instance, in the example of change in rhoticity in New York (Michael 2014). In the case of effects of high-status or standard varieties, ideology may suppress natural processes of change / spontaneous change (Kroch 1978). "Natural" change does not involve any particular social motivation and reflects the natural condition of language. The question that arises is why some classes resist "natural" change. Kroch's (1978) proposal was that dominant classes show a general social conservatism that also triggers resistance to spontaneous innovation.

Women have been considered the gender that leads changes from above (Labov 2001: 274). However, women's role is not restricted to processes above the conscious awareness alone. As Labov (1990; Labov's Gender Paradox) has shown, in the case of change from above, women tend to adopt prestige forms at a higher rate than men, but, in the case of change from below, women's language also includes innovative forms in higher frequencies than men's language (Nevalainen \& Raumolin-Brunberg 2003; Raumolin-Brunberg 2005). It appears that women lead instances of change from above that involve new prestige forms of higher-ranked groups. On the other hand, men initiate changes from below that do not involve accepted norms but relate to the vernacular. Other studies have also demonstrated the role of women in the supralocalization of new forms (Milroy \& Milroy 1993) and, in general, in the spread of linguistic features from their area of origin to neighboring regions (Nevalainen \& Raumolin-Brunberg 2003: 112). It is obvious that the use of prestige forms by women always depends on the possibility of access to these forms: for instance, the access of women to prestigious varieties of Early Modern English, classical languages and administrative texts, appears to have been extremely restrictive (Fletcher 1995; Raumolin-Brunberg 2005). The decline of multiple negation ${ }^{7}$ has been analyzed as an example of change influenced by characteristics of the

7 E.g., I'l never be so lasie no more but rise by five a cloke rather than mise wrighting any more (1677(?), Mary Stuart; 68; in Nevalainen 2000: 50). 
genders. Professional men (and social aspirers) promoted the decline of multiple negation, according to the model of administrative language. Differences between genders appeared also within the upper ranks: upper-rank women used multiple negation more frequently than upper-rank men (Nevalainen 1998, 2000). In another example, changes in pronunciation again contrast the role of women and men: according to several studies, women in New York, for instance, demonstrate a higher degree of use of prestige phonological variants that are imposed from above, whereas men's language in Martha's Vineyard shows examples of change in pronunciation below the level of social awareness. More specifically, working-class men adopt phonological variants that are nonstandard and serve as "solidarity markers" (Wodak \& Benke 1997).

The distribution of old and new forms appears to be less predictable. The old forms may be attested persistently (Kim 2012). According to Labov (1994), speakers learn the new forms, in the case of change from above, after they have acquired the vernacular. The change from multiple to single negation offers an example of distribution of old and new forms. This change has not been completed: in (social) dialects of English, multiple negation is a norm; but, in other dialects, speakers avoid using multiple negation in formal contexts, but it is still included in less formal contexts, in the vernacular (Kim 2012).

5. State of the art: Hypothesized changes from above in the diachrony of English

We have already discussed above some parameters related to the decline of multiple negation. The decline of multiple negation is also a significant typical example of investigation of the possibility of change from above. Multiple negation is attested in the language of upper class and was not stigmatized at all until the $16^{\text {th }}$ century; see (1) (from Nevalainen 2000: 50).

\section{(1) And that sawe y never yn no place but ther (1466(?), John Yeme; I, 78)}

Nevalainen has presented in detail the diachrony of multiple negation: Multiple negation was replaced by a single negation followed by nonassertive indefinites (ever, any, etc), in the early $16^{\text {th }}$ century. The above change was completed by the end of the $17^{\text {th }}$ century (Nevalainen 1998: 273). The decline of multiple negation was initiated in administrative language by social aspirers and professional men, and multiple negation disappeared first in formal writings (Nevalainen \& Raumolin-Brunberg 2003: 128, 150; Rissanen 1999). Within the framework of Generative Grammar, van Gelderen (2004) has shown the role of the prescriptive prohibition against multiple negation. There is a correlation between the prescriptive prohibition against multiple negation and the reason that a new Spec 
in the syntactic structure was not introduced in Standard English and, therefore, the negation cycle that favors a reintroduction of multiple negation was interrupted.

A second typical example of exploration of change from above derives from studies of the development of relative clauses. The hypothesis of change from above in this case is based on the popularity of books such as Fowler's, the introduction of $\boldsymbol{w h}$-forms into the speech of Tynesiders (Beal \& Corrigan 2007), and the association of this innovation with characteristic of animacy. Fowler (1926) suggests the usage of which in non-defining (nonrestrictive) clauses and of that in defining (restrictive) clauses. See (2).

(2) "Whereas it might seem orderly that, as who is appropriate to persons, so that should have been appropriated to things... we find in fact that the antecedent of that is often personal... Such peculiarities are explicable, but not now curable; they are inherent in the relative apparatus that we have received and are bound to work with." (Fowler 1926: 634-635; emphasis added)

That was a relative marker in English from early on. Wh-forms can be found as relative pronouns in Middle English. The hypothesis of the emergence of whforms as a change from above appears in many studies (Romaine 1980; Tottie 1997). Wh-forms were first used as relative pronouns and were confined to formal use (Tagliamonte 2006). Ball (1996) also observes a clear lag in the case of $w h$ forms between spoken usage and the more literary texts. Who was the last whform to develop (Romaine 1982: 223); its early examples are reported in 1426 (Rydén 1983: 127). The diachronic tendency is for the frequency of who with human subjects to increase and for the use of that to be restricted more and more to non-human subjects. Earlier studies also proposed a centuries-old change from above for who (Romaine 1982). In this case, the important parameter concerns the imitation of Latin and French (Mustanoja 1960: 199-200). According to Mustanoja, the $w h$-forms were adopted from the acrolects of Latin and French. Romaine (1982) also identifies the introduction of the $w h$-forms with prestige borrowing; see (3).

(3) "[...] the entrance of WH by way of the most complex styles of writing and syntactic positions does suggest a pattern of external prestige borrowing or 'change from above' in Labov's terms."

(Romaine 1982: 212)

We observe that there is consensus in the relevant studies that the $w h$-forms were introduced into the relativization system through formal registers (e.g., Romaine 
1982: 234; Dekeyser 1984; Montgomery 1989). Barber (1997: 214) mentions that the development towards the dominance of who should be seen as typical of a formal literary style, whereas that remained dominant in the informal style. Moreover, Romaine (1982: 212) argues that the diffusion of the $w h$-forms is completed in the modern written language, but it has not affected the spoken language. Actually, who is the prestige form in urban dialects of English and is associated with middle-class and well-educated speakers (Romaine 1982; Ball 1996; Beal \& Corrigan 2002; D'Arcy \& Tagliamonte 2010). On the other hand, who is not equally productive in "older, peripheral, and conservative varieties" (Tagliamonte, Smith \& Lawrence 2005; D'Arcy \& Tagliamonte 2010: 383-384).

With regard to the shift of the English syntax from a synthetic to a periphrastic type, it has been suggested that the English constructions of periphrastic comparison of are not the result of a language-internal change but of a historical change from above (D'Arcy 2012), primarily under the prestige influence of Latin, and, to a degree, of French, as well (Mustanoja 1960: 279). This proposed type of change from above is easily visible in writing: the variation between synthetic and periphrastic comparison is a common situation, especially with mono- and bisyllabic adjectives. The latter parameter (i.e., mono- and bisyllabic adjectives) is not significant in oral speech: the diffusion of periphrastic comparison is completed in oral speech and the options are conditioned by individual adjectives in oral speech (D'Arcy 2012).

A well-known example of studies that tried to identify the role of change from above concerns studies of the English passive progressive. Even though there is consensus that the development of the English progressive should be analyzed as a change from below, many scholars have emphasized the adoption of the passive progressive as conscious use of a restricted group of speakers, the ColeridgeSouthey circle (Denison 1993; Pratt \& Denison 2000; Killie 2004).

The diffusion of emerging supraregional forms constitutes a typical example of investigation of possible changes from above. For example, as is well known, the third person singular suffix in the $15^{\text {th }}$ century was $-t h$ in the South, $-s$ in the North, and the two forms appeared in competition in London. The distribution was different at the beginning of the $16^{\text {th }}$ century: according to some analyses, the -th suffix was promoted from above because it was the suffix found in the official documents issued by the Chancery. It was also the suffix that other professionals, and, especially, early printers favored (Nevalainen \& Raumolin-Brunberg 2000). ${ }^{8}$ In the second half of the $16^{\text {th }}$ century, the diffusion of the $-s$ suffix occurs as a change from below: $-s$ spreads from the lower social ranks and the colloquial language and seems to be first admitted into more productive use in London in

8 This means that the - th suffix would have been the suffix of the third person singular indicative present, if Standard English had been codified in the first half of the $16^{\text {th }}$ century. 
correspondence (Nevalainen \& Raumolin-Brunberg 2000). On another aspect of this distribution, see Hernández-Campoy, Conde-Silvestre \& García-Vidal in this volume.

If we move now from the development of the particular norms or patterns that have been analyzed as affected by change from above to the prestige dialects / languages or contexts that facilitated a hypothesized change from above, we should notice that the following parameters have been regarded as significant factors: the prestige of Latin, the borrowing from Anglo-Norman, the process of standardization, the importance of prescriptivism and the role of networks and individuals.

Latin constituted the prestige / High variety of England early on and throughout the Middle Ages. It had all characteristics of a lingua franca of religion, literature, education, and law. Borrowing from Latin retained its importance for many centuries and became widespread to a significant degree during the Renaissance period. It was due to a contrast to Latin that English was considered too impoverished to describe any new development (Blank 2006).

Anglo-Norman became the administrative, literary and religious variety of England after the Norman Conquest of 1066. In the same period, in contrast to Anglo-Norman, English was the Low variety in a triglossic (Anglo-Norman, Latin, and English) context. Anglo-Norman developed into a High variety of England and covered functions that overlapped with Latin to a degree; AngloNorman was acquired by professionals and social aspirers (Trotter 2000).

Late Middle English standardization is related to the selection and diffusion of a dialect in the early $15^{\text {th }}$ century. The selected reference dialect is associated with the royal writing offices, the Chancery and the Signet Office (Samuels 1963; Fisher 1996). Many studies have attempted to show the role of the royal writing offices in the spread of several norms to private writing (Hernández-Campoy \& Conde Silvestre 1999), in the process of standardization or vernacularization of genres, such as the genre of scientific writing (Wright 2000), and in the emergence of written norms in Late Middle English (Smith 1996). The London region becomes the center of supralocalization of many linguistic innovations (e.g., of the subject pronoun you) from the early $16^{\text {th }}$ century onwards. Nurmi (1999: 163-185), for instance, proposes that the arrival of the Stuart Court in London (around 1600) affected the prestige patterns to a degree. ${ }^{9}$ The dialectalization of Scots and the emergence of an English standard have attracted the interest of researchers; for instance, the spread of $d o$-support to Scotland can

9 Nevalainen \& Raumolin-Brunberg (2003) have presented how a number of grammatical changes diffused among the population of England: they have shown that variation exists in the rate of change and that several processes of change correlate with region, register, social status, and gender. 
be seen as a "change from above" (Klemola 2002: 204). According to Klemola (2002), periphrastic $d o$ was introduced into Scots prose in the second half of the $16^{\text {th }}$ century due to influence from England (cf. also Ljosland 2012).

Late Modern prescriptivism is related to linguistic ideology, which, as seen above, forms one of the major aspects of what we define as change from above. Prescriptivism in the form of comments on correct usage is rare in the early modern period and develops as a prescriptive ideology in the $18^{\text {th }}$ century (Raumolin-Brunberg 2005). Politeness, for instance, also grew into a significant linguistic ideology in the $18^{\text {th }}$ century (Klein 1994).

The Late Modern English period has also been the center of studies that attempt to reveal the role of networks and individuals. Tieken-Boon van Ostade (1996, 2000a, 2000b), for instance, has examined the hypothesis of a role of the language of well-known individual informants in language change based on their network contacts. The language of the prescriptive grammarian Robert Lowth constitutes a significant example (Tieken-Boon van Ostade 1997, 2005).

Bergs (2011) analyzed the role of social networks in the Middle English Paston Letters (1421-1503): he explored in detail the spread of the whrelativizers, the replacement of $\langle\mathrm{h}->$ pronouns by borrowed $\langle$ th- $>$ pronouns, and the spread of the light verb constructions. Bergs revealed the role of the individual in the change of morphosyntactic structures.

\section{New perspectives: The contribution of the present special issue}

The articles of the special issue originate from the Seminar "Change from above in the history of English," organized by Nikolaos Lavidas and Jim Walker (Université Lumière Lyon 2), held on 22 August 2016 in Galway, Ireland, and arranged as a part of the ESSE (European Society for the Study of English) Conference 2016 (22-26 August 2016; see https://www.esse2016.org/ seminars.html). All of the contributions to this special issue examine or question the hypothesis of a change from above in the history of English. They thus open new perspectives in the research of change from above in the diachrony of English. All articles pay special attention to the analysis of different perspectives through which change from above (as an "importation of elements from other systems"; Labov 2007) has been considered a parameter for the diachronic development of English and to the way that the explanations are strictly influenced from the theory of language. Accordingly, the issues addressed in the papers collected within this special issue include modern approaches to the analysis of change from above, the connection of change from above to language contact, the role of prescriptive rules and prestige languages, and the ideological evaluation of variation and change from above. Moreover, the papers discuss, among other phenomena, the (re)introduction of elements by the dominant social 
class in various stages of the history of English, their correlation with changes in other features, their (non)integration into the vernacular system, and the question of the coexistent systems.

The contributors offer a systematic presentation of many aspects of change from above in the history of English, such as the relationship between quotations and change from above (Don Chapman), the role of change from above and prescriptivism in the pronouncing dictionaries of English (Nicolas Trapateau \& Jean-Louis Duchet), the parameter of intra-speaker variation and change (Juan M. Hernández-Campoy, J. Camilo Conde-Silvestre \& Tamara García-Vidal), and the role of Elfric in the creation / development of English terminology (Yekaterina Yakovenko). All articles examine the hypothesis that speakers play a significant role in cases of language change; they explore: the role of great authors with regard to quotations that become part of the vocabulary of the language; the role of the orthoepist Walker, whose dictionary reflects the pressure in favor of changes from above in vowel quality; how the spelling innovation of <th> appears in the correspondence of John Paston I and why intra-speaker variation can be related to change from above; or, how Ælfric probably affected the emergence of new terminology.

The article by Don Chapman on the relationship between quotations and language change examines a case related to all periods of the development of English and, moreover, included in most language histories (which try to connect major authors to significant lexical innovations). The study shows that the process of incorporating a quotation is an example of change from above that can be located in several periods of the development of English; the incorporation of a quotation resembles other language change processes and exemplifies change from above in both senses: in the sense of change above the level of consciousness as well as in the sense of change triggered by highprestige languages. The other articles of the special issue refer to case studies on changes that appeared in English in three different periods, demonstrating examples of changes from above from completely different stages of the diachrony of English (Early Modern - Middle - Old English). Starting with more recent changes and moving toward earlier changes, Nicolas Trapateau \& Jean-Louis Duchet's paper investigates phonological changes of the $18^{\text {th }}$ century, Juan M. Hernández-Campoy, J. Camilo Conde-Silvestre, and Tamara García-Vidal's article examines spelling innovations of the $15^{\text {th }}$ century, and Yekaterina Yakovenko's article discusses the innovative linguistic terminology of the $10^{\text {th }}$ century. All studies reflect significant developments of the particular periods: the change in the pronunciation of vowels in the $18^{\text {th }}$ century, the variation in spelling in the $15^{\text {th }}$ century and the later standardization of spelling, and the coinage of linguistic terminology as well as the lexical influence of Latin in the $10^{\text {th }}$ century. All studies examine lexical or morpho-phonological 
aspects of change and provide indirect evidence in favor of a possible different type of relationship between change from above and (a) lexicon and morphophonology on the one hand and (b) syntax on the other hand. Nicolas Trapateau and Jean-Louis Duchet present a systematic investigation of John Walker's Critical Pronouncing Dictionary $(1791,1809)$, the most complete and cumulative of all such dictionaries of the time, and show that an orthoepist like Walker often reflects the pressure in favor of changes from above in vowel quality and resistance to such changes in matters of stress placement. On the other hand, we should also notice that Walker also linked analogy to the "vernacular instinct," in a manner that promoted variant forms and witnessed a change from below. Juan M. Hernández-Campoy, J. Camilo Conde-Silvestre, and Tamara García-Vidal explore the characteristics of a spelling change through intra-speaker variation in English historical correspondence corpora. Their analysis focuses on the deployment of the spelling innovation $\langle t h\rangle$ in the Paston letters and especially in the correspondence of John Paston I (14211466), one of the core family members with extensive social and geographical mobility. The analysis of $\langle t h\rangle$ in connection to the addressees of his letters and the formality of the situation allows the detection of patterns of variation in spelling, following present-day models of stylistic interpretation such as audience design and attention to speech, which confirm a relationship between change from above and the emergence of new patterns of variation in spelling. Yekaterina Yakovenko focuses on linguistic terminology created or used by Ælfric in his Grammar (Excerptiones de arte grammatica anglice) that reflected late Latin grammars. The article addresses the question of the role of written forms of contact as a type of source of a change from above as well as the question of lexical innovations of an author as part of a process of a language change.

Through different perspectives and investigation of various phenomena of change in the history of English, the articles in the present special issue open two major directions of research in the area of change from above: (a) The first direction concerns the relationship between change from above and language contact. A common characteristic of approaches is that changes from above are related to language contact; this is unavoidable if change from above is identified with borrowing from a prestigious language. (b) The second direction traces the position of change from above in the process of change: can a change from above only delay the introduction of a new characteristic or the completion of a typical change (cf. the early approach of Kroch (1978), among others)? Alternatively, can this type of change also initiate the introduction of new features? The articles of this special issue exemplify instances of these two directions of research in the case of innovative quotations and terminology and in new phonological and spelling tendencies. The dialogue between different approaches and theories, 
which can be facilitated through the application of common methodologies (such as, the methodology of corpus studies) can provide the stable criteria needed to test hypotheses, such as the hypothesis of change from above in the development of various characteristics and patterns.

\section{REFERENCES}

Ball, Catherine. 1996. A diachronic study of relative markers in spoken and written English. Language Variation and Change 8.2. 227-258. DOI: 10.1017/S0954394500001150

Barber, Charles. 1997. Early Modern English. Edinburgh: Edinburgh University Press.

Beal, Joan C. \& Karen P. Corrigan. 2002. Relatives in Tyneside and Northumbrian English. In Patricia Poussa (ed.), Relativization on the North Sea littoral, Munich: Lincom Europa. 125-134.

Beal, Joan C. \& Karen P. Corrigan. 2007. "Time and Tyne": A corpus-based study of variation and change in relativization stategies in Tyneside English. In Stephan Elspaß, Nils Langer, Joachim Scharloth, and Wim Vandenbussche (eds.), Germanic language histories 'from below' (1700-2000), Berlin \& New York, NY: Walter de Gruyter, 99-114. DOI: 10.1515/9783110925463.99

Bergs, Alexander. 2011. Social networks and historical sociolinguistics. Studies in morphosyntactic variation in the Paston Letters (1421-1503). Berlin \& Boston, MA: De Gruyter Mouton. DOI: 10.1515/9783110923223

Bickerton, Derek. 1980. Decreolisation and the creole continuum. In Albert Valdman \& Arnold Highfield (eds.), Theoretical orientations in creole studies, New York, NY: Academic Press. 109-127.

Blank, Paula. 2006. The Babel of Renaissance English. In Lydia Mugglestone (ed.), The Oxford history of English, Oxford: Oxford University Press. 262-297.

Curzan, Anne. 2014. Fixing English: Prescriptivism and language history. Cambridge: Cambridge University Press. DOI: 10.1017/CBO9781139107327

D'Arcy, Alexandra. 2012. The diachrony of quotation: Evidence from New Zealand English. Language Variation and Change 24.3. 343-369. DOI: 10.1017/S0954394512000166

D'Arcy, Alexandra \& Sali A. Tagliamonte. 2010. Prestige, accommodation, and the legacy of relative who. Language in Society 39.3. 383-410. DOI: 10.1017/S0047404510000205

Dekeyser, Xavier. 1984. Relativizers in early Modern English: A dynamic quantitative study. In Jacek Fisiak (ed.), Historical syntax. Berlin: Mouton de Gruyter. 61-87. DOI: $10.1515 / 9783110824032.61$

Denison, David. 1993. Some recent changes in the English verb. In Maurizio Gotti (ed.), English Diachronic Syntax, Milan: Guerini. 15-33.

Denison, D. 2007. Syntactic surprises in some English letters: The underlying progress of the language. In Stephan Elspaß, Nils Langer, Joachim Scharloth, and Wim Vandenbussche (eds.), Germanic language histories 'from below' (1700-2000), Berlin \& New York, NY: Walter de Gruyter. 115-128. DOI: 10.1515/9783110925463.115

Fisher, John H. 1996. The emergence of Standard English. Lexington, KY: University of Kentucky Press. 
Fletcher, Anthony. 1995. Gender, sex, and subordination in England, 1500-1800. New Haven, CT: Yale University Press.

Fowler, Henry W. 1926. A dictionary of Modern English usage. Oxford: Oxford University Press. Gelderen, Elly van. 2004. Economy, innovation, and prescriptivism: From Spec to Head and Head to Head. Journal of Comparative Germanic Linguistics 7. 59-98. DOI: 10.1023/B:JCOM.0000003601.53603.b2

Guy, Gregory R. 1990. The sociolinguistic types of language change. Diachronica 7.1. 47-67. DOI: 10.1075/dia.7.1.04guy

Hernández-Campoy, Juan M. \& J. Camilo Conde-Silvestre. 1999. The social diffusion of linguistic innovations in fifteenth century England: Chancery spellings in private correspondence. Cuadernos de Filología Inglesa 8. 251-274.

Kerswill, Paul. 1996. Children, adolescents, and language change. Language Variation and Change 8.2. 177-202. DOI: $10.1017 /$ S0954394500001137

Killie, Kristin. 2004. Subjectivity and the English progressive. English Language and Linguistics 8.1. 25-46. DOI: $10.1017 /$ S1360674304001236

Kim, Dong-Hyuk. 2012. Early Biblical Hebrew, Late Biblical Hebrew, and linguistic variability: A sociolinguistic evaluation of the linguistic dating of biblical texts. Leiden: Brill.

Klein, Lawrence E. 1994. Shaftesbury and the culture of politeness: Moral discourse and cultural politics in early eighteenth-century England. Cambridge: Cambridge University Press. DOI: $10.1017 / \mathrm{CBO} 9780511659973$

Klemola, Juhani. 2002. Periphrastic DO: Dialectal distribution and origins. In Markku Filppula Juhani Klemola \& Heli Pitkänen (eds.), The Celtic roots of English, Joensuu: University of Joensuu. 199-210.

Kroch, Anthony S. 1978. Toward a theory of social dialect variation. Language in Society 7.1. 1736. DOI: $10.1017 /$ S0047404500005315

Kroch, Anthony S. 1989. Reflexes of grammar in patterns of language change. Language Variation and Change 1.3. 199-244. DOI: 10.1017/S0954394500000168

Labov, William. 1965. On the mechanism of linguistic change. Georgetown Monographs on Language and Linguistics 18. 91-114.

Labov, William. 1966 [2006]. The social stratification of English in New York City. Cambridge: Cambridge University Press. DOI: 10.1017/CBO9780511618208

Labov, William. 1990. The intersection of sex and social class in the course of linguistic change. Language Variation and Change 2.2 205-254. DOI: 10.1017/S095439450000033

Labov, William. 1994. Principles of linguistic change. Vol. 1: Internal factors. Oxford \& Cambridge, MA: Blackwell.

Labov, William. 2001. Principles of linguistic change. Vol. 2: Social factors. Oxford \& Cambridge, MA: Blackwell.

Labov, William. 2007. Transmission and diffusion. Language 83.2, 344-387. DOI: 10.1353/lan.2007.0082

Labov, William., Sharon Ash \& Charles Boberg. 2006. The Atlas of North American English: Phonetics, phonology and sound change. Berlin: Mouton de Gruyter. DOI: $10.1515 / 9783110167467$

Lavidas, Nikolaos \& Alexander Bergs. 2020. On historical language contact in English and its types: State of the art and new directions. Linguistics Vanguard 6s2: 20200010. DOI: 10.1515/lingvan-2020-0010 
Ljosland, Ragnhild. 2012. The establishment of the Scots language in Orkney. New Orkney Antiquarian Journal 6. 65-80.

Macaulay, Ronald. 2006. Pure grammaticalization: The development of a teenage intensifier. Language Variation and Change 18.3 267-283. DOI: 10.1017/S0954394506060133

Michael, Lev. 2014. Social dimensions of language change. In Claire Bowern \& Bethwyn Evans (eds.), The Routledge Handbook of Historical Linguistics, London: Routledge. DOI: 10.4324/9781315794013.ch22

Milroy, James \& Leslie Milroy. 1993. Mechanisms of change in urban dialects. The role of class, social network and gender. International Journal of Applied Linguistics 3.1, 57-77. DOI: 10.1111/j.1473-4192.1993.tb00043.x

Montgomery, Michael B. 1989. The standardization of English relative clauses. In Joseph B. Trahern (ed.), Standardizing English: Essays in the history of language change, in Honor of John Hurt Fisher, Knoxville, TN: University of Tennessee Press. 111-138.

Mustanoja, Tauno. F. 1960. A Middle English syntax. Helsinki: Société Néophilologique.

Nevalainen, Terttu. 1998. Social mobility and the decline of multiple negation in Early Modern English. In Jacek Fisiak \& Marcin Krygier (eds.), Advances in English historical linguistics, Berlin \& New York, NY: Mouton de Gruyter. 263-292. DOI: 10.1515/9783110804072.263

Nevalainen, Terttu. 2000. Processes of supralocalisation and the rise of Standard English in the early Modern period. In Ricardo Bermúdez-Otero, David Denison, Richard M. Hogg \& C. B. McCully (eds.), Generative theory and corpus studies: A dialogue from 10 ICEHL. Berlin \& New York, NY: Mouton de Gruyter, 329-372. DOI: $10.1515 / 9783110814699.329$

Nevalainen, Terttu. 2006. Negative concord as an English 'vernacular universal': Social history and linguistic typology. Journal of English Linguistics 34.3. 257-278. DOI: $10.1177 / 0075424206293144$

Nevalainen, Terttu \& Helena Raumolin-Brunberg. 2000. The changing role of London on the linguistic map of Tudor and Stuart England. In Dieter Kastovsky \& Arthur Mettinger (eds.), The history of English in a social context: A contribution to historical sociolinguistics, Berlin \& New York, NY: Mouton de Gruyter. 279-338. DOI: 10.1515/9783110810301.279

Nevalainen, Terttu \& Helena Raumolin-Brunberg. 2003. Historical sociolinguistics: Language change in Tudor and Stuart England. London: Pearson Education.

Nurmi, Arja. 1999. A social history of perophrastic DO. Helsinki: Société Néophilologique.

Pratt, Lynda \& David Denison. 2000. The language of the Southey-Coleridge circle. Language Sciences 22.3. 401-422. DOI: 10.1016/S0388-0001(00)00013-9

Raumolin-Brunberg, Helena 2005. Language change in adulthood: Historical letters as evidence. European Journal of English Studies 9.1. 37-51. DOI: 10.1080/13825570500068125

Rissanen, Matti. 1991. Spoken language and the history of do-periphrasis. In Dieter Kastovsky (ed.), Historical English syntax, Berlin \& New York, NY: Mouton de Gruyter. 321342. DOI: $10.1515 / 9783110863314.321$

Rissanen, Matti. 1999. Syntax. In Roger Lass (ed.), The Cambridge history of the English language. Vol. 3: 1476-1776. Cambridge: Cambridge University Press. 187-331.

Romaine, Suzanne. 1980. A critical overview of the methodology of urban British sociolinguistics. English World-Wide 1.2. 163-198. DOI: 10.1075/eww.1.2.02rom

Romaine, Suzanne. 1982. Socio-historical linguistics: Its status and methodology. Cambridge: Cambridge University Press. 
Rydén, Mats. 1983. The emergence of who as a relativizer. Studia Linguistica 37.2. 126-134. DOI: 10.1111/j.1467-9582.1983.tb00317.x

Samuels, M. L. 1963. Some applications of Middle English dialectology. English Studies 44. 8194. DOI: $10.1080 / 00138386308597155$

Smith, Jeremy. 1996. An historical study of English: Function, form and change. London \& New York, NY: Routledge.

Tagliamonte, Sali. A. 2006. "So cool, right?" Canadian English entering the 21st century. Canadian Journal of Linguistics 51.2-3. 309-331. DOI: 10.1017/S0008413100004126

Tagliamonte, Sali. A., Jennifer Smith \& Helen Lawrence. 2005. No taming the vernacular! Insights from the relatives in northern Britain. Language Variation and Change 17.1. 75-112. DOI: $10.1017 /$ S0954394505050040

Tieken-Boon van Ostade, Ingrid. 1996. Social network theory and eighteenth-century English: The case of Boswell. In Derek Britton (ed.). English historical linguistics 1994, Amsterdam \& Philadelphia, PA: Benjamins. 327-337. DOI: 10.1075/cilt.135.23tie

Tieken-Boon van Ostade, Ingrid. 1997. Lowth's corpus of prescriptivism. In Terttu Nevalainen \& Leena Kahlas-Tarkka (eds.), To explain the present: Studies in the changing English language in honour of Matti Rissanen, Helsinki: Société Néophilologique. 451-463.

Tieken-Boon van Ostade, Ingrid. 2000a. Robert Dodsley and the genesis of Lowth's Short introduction to English grammar. Historiographia Linguistica 27.1. 21-36. DOI: 10.1075/hl.27.1.03tie

Tieken-Boon van Ostade, Ingrid. 2000b. Social network analysis and the language of Sarah Fielding. European Journal of English Studies 4.3. 291-301. DOI: 10.1076/13825577(200012)4:3;1-S;FT291

Tieken-Boon van Ostade, Ingrid. 2005. Of social networks and linguistic influence: The language of Robert Lowth and his correspondents. In: J. Camilo Conde-Silvestre \& Juan Hernández-Campoy (eds.), Sociolinguistics and the history of English: Perspectives and problems. Murcia: Universidad de Murcia. 135-157.

Tottie, Gunnel. 1997. Relatively speaking: Relative marker usage in the British National Corpus. In Terttu Nevalainen \& Leena Kahlas-Tarkka (eds.), To explain the present: Studies in the changing English language in honour of Matti Rissanen, Helsinki: Société Néophilologique. 465-481.

Trotter, David. 2000. Anglo-Norman'. In Glanville Price (ed.), Languages of the British Isles, Oxford: Blackwell. 197-206.

Trudgill, Peter. 1974. The social differentiation of English in Norwich. Cambridge: Cambridge University Press.

Wodak, Ruth \& Gertraud Benke. 1997. Gender as a sociolinguistic variable: New perspectives on variation studies. In Florian Coulmas (ed.), The handbook of sociolinguistics, Oxford: Blackwell. 127-150. DOI: 10.1002/9781405166256.ch8

Wright, Laura. 2000. The development of Standard English, 1300-1800: Theories, descriptions, conflicts. Cambridge: Cambridge University Press. DOI: 10.1017/CBO9780511551758 